\title{
Physical Hybrid of Nanographene/Carbon Nanotubes as Reinforcing Agents of NR-Based Rubber Foam
}

\author{
Sahar Shojaie $^{1}$, Ali Vahidifar ${ }^{1}$, Ghasem Naderi ${ }^{2}$, Elham Shokri ${ }^{3}$, Tizazu H. Mekonnen ${ }^{4}$ \\ and Elnaz Esmizadeh $5, *$ (D)
}

1 Department of Polymer Science and Engineering, Faculty of Engineering, University of Bonab, Bonab P.O. Box 5551761167, Iran; Sahar.Shojaeiiii318075@gmail.com (S.S.); Ali.Vahidifar@airboss.com (A.V.)

2 Department of Polymer Processing, Iran Polymer and Petrochemical Institute, Tehran P.O. Box 1497713115, Iran; G.Naderi@ippi.ac.ir

3 Department of Chemical Engineering, Faculty of Engineering, University of Bonab, Bonab P.O. Box 5551761167, Iran; Elham.Shokri@bonabu.ac.ir

4 Department of Chemical Engineering, Faculty of Engineering, University of Waterloo, Waterloo, ON N2L 3G1, Canada; Tizazu.Mekonnen@uwaterloo.ca

5 Construction Research Center, National Research Council Canada, 1200 Montreal Rd., Ottawa, ON K1A 0R6, Canada

* Correspondence: Elnaz.Esmizadeh@nrc-cnrc.gc.ca

Citation: Shojaie, S.; Vahidifar, A.; Naderi, G.; Shokri, E.; Mekonnen, T.H.; Esmizadeh, E. Physical Hybrid of Nanographene/Carbon Nanotubes as Reinforcing Agents of NR-Based Rubber Foam. Polymers 2021, 13, 2346. https://doi.org/10.3390/polym13142346

Academic Editor: Maria

Gabriella Santonicola

Received: 11 June 2021

Accepted: 14 July 2021

Published: 17 July 2021

Publisher's Note: MDPI stays neutral with regard to jurisdictional claims in published maps and institutional affiliations.

Copyright: (c) 2021 by the authors. Licensee MDPI, Basel, Switzerland. This article is an open access article distributed under the terms and conditions of the Creative Commons Attribution (CC BY) license (https:// creativecommons.org/licenses/by/ $4.0 /)$.

\begin{abstract}
Natural rubber (NR) foams reinforced by a physical hybrid of nanographene/carbon nanotubes were fabricated using a two-roll mill and compression molding process. The effects of nanographene (GNS) and carbon nanotubes (CNT) were investigated on the curing behavior, foam morphology, and mechanical and thermal properties of the NR nanocomposite foams. Microscope investigations showed that the GNS/CNT hybrid fillers acted as nucleation agents and increased the cell density and decreased the cell size and wall thickness. Simultaneously, the cell size distribution became narrower, containing more uniform multiple closed-cell pores. The rheometric results showed that the GNS/CNT hybrids accelerated the curing process and decreased the scorch time from 6.81 to $5.08 \mathrm{~min}$ and the curing time from 14.3 to $11.12 \mathrm{~min}$. Other results showed that the GNS/CNT hybrid improved the foam's curing behavior. The degradation temperature of the nanocomposites at $5 \mathrm{wt} . \%$ and $50 \mathrm{wt}$.\% weight loss increased from $407^{\circ} \mathrm{C}$ to $414^{\circ} \mathrm{C}$ and from $339{ }^{\circ} \mathrm{C}$ to $346^{\circ} \mathrm{C}$, respectively, and the residual ash increased from $5.7 \mathrm{wt} . \%$ to $12.23 \mathrm{wt} . \%$ with increasing hybrid nanofiller content. As the amount of the GNS/CNT hybrids increased in the rubber matrix, the modulus also increased, and the $\mathrm{T}_{\mathrm{g}}$ increased slightly from $-45.77^{\circ} \mathrm{C}$ to $-38.69^{\circ} \mathrm{C}$. The mechanical properties of the NR nanocomposite foams, including the hardness, resilience, and compression, were also improved by incorporating GNS/CNT hybrid fillers. Overall, the incorporation of the nano hybrid fillers elevated the desirable properties of the rubber foam.
\end{abstract}

Keywords: rubber foam; polymer nanocomposites; mechanical response; hybrid nanofillers; natural rubber

\section{Introduction}

In recent decades, polymer nanocomposites have received a great deal of attention, since adding only a small fraction of nanofillers to the polymer matrix significantly improves their properties [1]. This concept has been successfully applied to thermoplastics [2], elastomers and thermoset elastomers [3]. Today, a wide array of different nanofillers are available, such as nanoclay [4], carbon nanotubes (CNTs) [5], graphene nanosheets (GNSs) [6,7], nano cellulose [8], and halloysite nanotubes [9], which are frequently used in polymer matrices as reinforcing agents. CNTs show many desirable properties related to flexibility, high strength, ability to withstand transverse and torsional displacements, tensile strength and compressive strength without breaking [10]. GNSs are recognized 
as one of the most effective nanomaterials because of their high potential for mechanicalproperty improvement due to the combination of enormous specific surface area, strong filler-matrix adhesion, and the extraordinary mechanical properties of the sp2 carbon bonding network [11]. Despite having numerous extraordinary properties, the commercialization of these two carbon nanomaterial allotropes is still limited due to their tendency to agglomerate (bundle and layer forming behavior for CNT and GNS, respectively) [12].

Rubber foam is an interesting material, as it can be used in a diverse range of applications, such as insulation, packaging, and cushioning. The foam can be fabricated according to specific requirements using different types of polymers and blowing agents. A foam's properties are controlled by its density, cell structure, and the chemistry of the raw materials used [13]. Rubber foams can be classified into two groups based on their cell structure: open-cell foams [14-16], where the gas phases (cells) are linked to each other, and closed-cell foams, in which the cells have isolated or separated cell walls [17]. The incorporation of various types of nanofiller has been a commonly used measure to improve the mechanical, thermal, and electrical properties of rubber foams [18]. However, there are still challenges in achieving a segregated filler network wherein the nanofillers are arranged to produce a 3-D network, which percolates the polymer volume. Recently, the combined use of nanofillers as a physical and chemical hybrid has exhibited a synergistic effect that led to outstanding enhanced performance of nanocomposites with respect to employing only one type of reinforcement [19-21]. Since the building blocks of a nanocomposite are of nanoscale, many interfaces exist between the two intermixed solid reinforcement phases and the superior properties arise from phase interactions at these interfaces. Ponnamma et al. showed that morphology of NR-CNT composite gradually evolves from a discontinuous set of aggregated clusters to a continuous 3-D network upon the replacement of CNT by nanographene by 50 percent (50:50 hybrid nanofiller) [22]. King et al. suggested that the synergism of CNT and GNS is derived from two main mechanisms: CNTs act as bridges between GNSs and GNSs fill the space between CNTs [23]. Shim et al. presented a predictive model to quantitatively explain the synergistic behavior of CNT/GNS hybrid, which was achieved by featuring an increased number of contacts between GNSs and CNTs [24].

The knowledge of how to control the properties of rubber foams reinforced by hybrid nanofillers is of fundamental importance in order to determine the final performance and application of the product. Although several studies on NR solid nanocomposites reinforced by hybrid nanomaterial are available [22], the literature still lacks information on their foams. Thus, the novelty of this work lies in its primary objective, which is to assess the fabrication of NR nanocomposite foams reinforced by a CNT/GNS hybrid. The present article intends to address the gap by studying how various CNT/GNS physical hybrid loadings influence the curing behavior, the foam morphology, and the mechanical and thermal properties of NR nanocomposite foams.

\section{Materials and Methods}

Standard Malaysian NR (SMR) with a trade name of SMR-20 (Mooney viscosity of ML $\left.(1+4) @ 100^{\circ} \mathrm{C}\right)$ was obtained from the Malaysian Rubber Company, Sungai Lalang, Malaysia. Non-functionalized (pristine) carbon nanotubes (CNTs) with an outer diameter of $8-15 \mathrm{~nm}(95 \%$ < purity) was purchased from Notrino, Iran. C-750 graphene nanosheets (GNSs) with a surface area of $750 \mathrm{~m}^{2} / \mathrm{g}$ and an average thickness of 1-5 nm were obtained from XG Science (Lansing, MI, USA). Sulfur, Carbon black, DMF, paraffin oil, MBTS(2-2'Dithiobis benzothiazole), CBS (N-cyclohexyl-2-benzothiazolesulfenamide), stearic acid, and $\mathrm{ZnO}$ were commercial grades. The chemical blowing agent azodicarbonamide (ADC) was provided by the Letai Chemical Plant (Beijing, China).

Before compounding, CNTs and GNSs were kept in an oven at $90{ }^{\circ} \mathrm{C}$ for $15 \mathrm{~h}$ to eliminate trace moisture. We dispersed $3.5 \mathrm{~g}$ of the dried CNTs and GNSs in $200 \mathrm{~mL}$ DMF (solvent) in a separate beaker. Each sample was exposed to an ultrasonic process (400 W) in three 5-min steps to improve the dispersion quality. 
An open two-roll mill was then used for compounding the formulation at an ambient temperature. For this, $20 \mathrm{~g}$ of NR was masticated in a two-roll mill for $1 \mathrm{~min}$ and dissolved in 200 cc of DMF under stirring. The pre-prepared CNTs/DMF solution was then added to half of the NR solution, and the GNSs/DMF solution was added to the other half of the NR solution and placed separately in an ultrasonic bath for two 30-min steps. The two dispersions were then mixed and placed in the same ultrasonic bath for $5 \mathrm{~min}$. To obtain a masterbatch, the samples were dried in a vacuum oven at $70{ }^{\circ} \mathrm{C}$ until all DMF was removed and the samples' weight remained unchanged. Table 1 shows the compounding formulations. First, $57 \mathrm{~g}$ NR was masticated in a two-roll mill for $5 \mathrm{~min}$, and after sufficient mastication, the masterbatch was carefully added, and the compounds were milled for $3 \mathrm{~min}$. Other compounding ingredients, except for the curing agent, were then fed gradually into the mill, and the compounding continued for $2 \mathrm{~min}$. In the end, the curing agent was added, and the compounding continued for another $2 \mathrm{~min}$.

Table 1. Formulation of NR/CNT/GNS nanocomposite foams.

\begin{tabular}{|c|c|c|c|c|c|c|c|c|c|c|c|c|}
\hline \multicolumn{12}{|c|}{ Ingredients } & \multirow{2}{*}{$\begin{array}{c}\text { Sample } \\
\text { Code }\end{array}$} \\
\hline $\begin{array}{c}\text { Master } \\
\text { Batch }\end{array}$ & ADC & Oil & Sulfur & $\mathrm{ZnO}$ & $\begin{array}{c}\text { Stearic } \\
\text { Acid }\end{array}$ & MBTS & CBS & CB & GNS & CNT & NR & \\
\hline 0 & 6 & 5 & 1.5 & 4.5 & 2 & 0.6 & 0.6 & 10 & 0 & 0 & 100 & S0 \\
\hline 0.771 & 6 & 5 & 1.5 & 4.5 & 2 & 0.6 & 0.6 & 10 & 0.1 & 0.1 & 100 & S0.1 \\
\hline 1.928 & 6 & 5 & 1.5 & 4.5 & 2 & 0.6 & 0.6 & 10 & 0.25 & 0.25 & 100 & S0.25 \\
\hline 3.857 & 6 & 5 & 1.5 & 4.5 & 2 & 0.6 & 0.6 & 10 & 0.5 & 0.5 & 100 & S0.5 \\
\hline 7.714 & 6 & 5 & 1.5 & 4.5 & 2 & 0.6 & 0.6 & 10 & 1 & 1 & 100 & S1 \\
\hline 11.571 & 6 & 5 & 1.5 & 4.5 & 2 & 0.6 & 0.6 & 10 & 1.5 & 1.5 & 100 & S1.5 \\
\hline 15.428 & 6 & 5 & 1.5 & 4.5 & 2 & 0.6 & 0.6 & 10 & 2 & 2 & 100 & $\mathrm{~S} 2$ \\
\hline
\end{tabular}

The cure behavior of the compounds was determined using an Oscillating Disk Rheometer (ODR) model 4308 (Zwick Co., Ulm, Germany) at a temperature of $160{ }^{\circ} \mathrm{C}$, according to ASTM D22044. An optical microscope was employed to study the foam morphology, cell size, and cell size distribution. Resilience was measured at a temperature of $25^{\circ} \mathrm{C}$ using a resilience tester (Frank GMBH, Birkenau, Germany), in accordance with ASTM D1054. A Shore-A type hardness test was performed at room temperature to measure the stiffness of the foams by a hardness tester (Zwick Co. 3100, Germany) according to ASTM D2240. To study the nanofiller's effect on the NR foams' mechanical properties, a compression test was performed using (Hiwa-400, Urmia, Iran) according to ASTM D412. Thermogravimetric analysis (TGA) was carried out to estimate the thermal stability of the foams using a Pyris TGA (Perkin-Elmer, Waltham, MA, USA) in the temperature range of $25^{\circ} \mathrm{C}$ to $1000{ }^{\circ} \mathrm{C}$ under an oxygen atmosphere at a heating rate of $10^{\circ} \mathrm{C} / \mathrm{min}$. To study the dynamical mechanical properties of samples, DMTA test was carried out using (DMA 2000 TRITEC, Edinburgh, England). The test was performed by applying a bending force with a frequency of $4 \mathrm{~Hz}$ at a heating rate of $10{ }^{\circ} \mathrm{C} / \mathrm{min}$ in the temperature range of $-100{ }^{\circ} \mathrm{C}$ to $100{ }^{\circ} \mathrm{C}$.

\section{Results and Discussion}

\subsection{Curing Behavior}

Controlling NR/CNT/GNS nanocomposite foams' curing process is essential to fabricate foams with specific properties and morphologies. The effect of the nanofiller's content on the curing behavior of rubber foams at $155^{\circ} \mathrm{C}$ is displayed in Figure 1. It can be seen that increasing the CNT and GNS content accelerates the curing process by decreasing the scorch time ( $t_{s}$, the time that the curing process starts), the curing time ( $t_{90}$, when the curing process achieves $90 \%$ ), the final torque or the torque of cured compounds $\left(M_{H}\right)$, and the delta torque or the torque difference between the cured and uncured compound $\left(\Delta M=M_{H}-M_{I}\right)$. However, it increased the curing rate $\left(C R I=\frac{100}{t_{90} \cdot t_{s}}\right)$ [25], the initial torque, 
or the torque of the uncured compounds $\left(M_{I}\right) . M_{90}$ can be calculated using Equation (1) [26] as follows:

$$
M_{90}=M_{I}+0.9\left(M_{H}-M_{I}\right)
$$

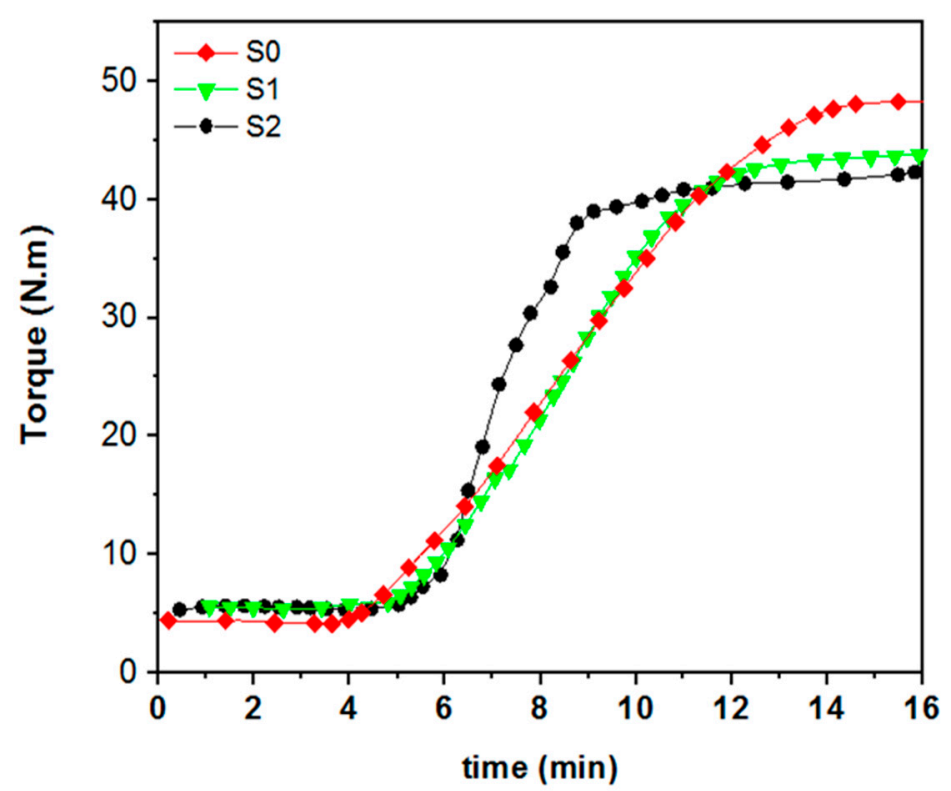

Figure 1. Rheometric curves of NR/CNT/GNS hybrid nanocomposite foams at $155^{\circ} \mathrm{C}$.

The result shows that the curing rate significantly increased with increasing CNT and GNS content from 0 to $2 \mathrm{phr}$, while decreasing the scorch time and the cure time from 6.81 to $5.08 \mathrm{~min}$ and from 14.3 to $11.12 \mathrm{~min}$, respectively. This could be related to the fact that CNT/GNS hybrid nanofiller can act as accelerators to the curing process, which is in agreement with what was observed for each nanofiller individually $[27,28]$. In addition, increasing the CRI from 13.34 (in the S0 sample) to 16.55 (in the S2 sample) showed that the cure rate had tremendously increased by increasing CNT/GNS content. The higher cure rate of S2 in comparison to S0 confirmed the accelerating effect of hybrid nanofiller on cure reaction of NR foam. As demonstrated in Table 2, the initial torque $\left(M_{I}\right)$ increased with nanofiller loading, which could be due to the increase in viscosity as a result of the presence of solid materials in the polymer matrix, which limits the chains ${ }^{\prime}$ mobility by creating physical interactions with NR chains. Restricted viscous motions of polymer chains' segments in presence of fillers and reinforcement were reported in the literature [29]. Additionally, adding higher amounts of the physical hybrids of CNT to GNS limits the polymer chains in the sintering reaction and reduces the amount of lattice created. Such a decrease in the percentage of networks created can be seen in reducing $M_{H}$ (Table 2) by adding higher amounts of nanohybrids.

Table 2. Curing characteristics of NR/CNT/GNS hybrid nanocomposite foams at $155^{\circ} \mathrm{C}$.

\begin{tabular}{|c|c|c|c|c|c|c|c|}
\hline $\begin{array}{c}\text { Sample } \\
\text { Code }\end{array}$ & $\begin{array}{c}M_{L} \\
(\mathrm{~N} \cdot \mathbf{m})\end{array}$ & $\begin{array}{c}M_{H} \\
(\mathrm{~N} \cdot \mathrm{m})\end{array}$ & $\begin{array}{c}M_{90} \\
(\mathrm{~N} \cdot \mathrm{m})\end{array}$ & $\begin{array}{c}\Delta M \\
(\mathrm{~N} \cdot \mathrm{m})\end{array}$ & $\begin{array}{c}T_{s} \\
\text { (min) }\end{array}$ & $\begin{array}{c}T_{90} \\
\text { (min) }\end{array}$ & $\begin{array}{c}C R I \\
(\% / \mathrm{min})\end{array}$ \\
\hline S0 & 4.68 & 48.1 & 43.76 & 43.42 & 6.81 & 14.3 & 13.35 \\
\hline S0.1 & 4.8 & 47.78 & 43.48 & 42.98 & 6.19 & 14.0 & 12.80 \\
\hline S0.25 & 5.01 & 48.31 & 43.98 & 43.3 & 6.08 & 13.9 & 12.78 \\
\hline S0.5 & 5.2 & 43.2 & 39.41 & 38 & 5.89 & 13.7 & 12.80 \\
\hline S1 & 5.34 & 43.5 & 39.68 & 38.16 & 5.63 & 12.5 & 14.55 \\
\hline S1.5 & 5.50 & 43.8 & 39.97 & 38.3 & 5.43 & 11.7 & 15.94 \\
\hline S2 & 5.46 & 42.5 & 38.79 & 37.04 & 5.08 & 11.12 & 16.55 \\
\hline
\end{tabular}




\subsection{Morphology}

To investigate the effect of the CNT/GNS hybrid on the cell structure of the NR nanocomposite foam samples, the morphology of the samples was studied using an optical microscope. Figure 2 displays images of the surface of NR/CNT/GNS foam nanocomposite samples. The qualitative investigation by optical microscopy showed that increasing the CNT/GNS hybrid content increased cell number and cell density while decreasing cell size and cell wall thickness. These changes in cell structure can be interpreted by the competition between the pressure of the released blowing agent and the rubber module that resists the growth of the bubble. The former is known as the driving force of the foaming process and the latter plays the role of inhibiting the force of the foaming process [30]. While these cavities have become more spherical in shape and closer to each other with the addition of CNT/GNS hybrid nanoparticles, they became more uniform overall. These results could be related to both the nucleation and the viscosity effect of the nanoparticles, and it is likely that the dispersed nanoparticles may act as nucleating sites that facilitate the bubbling process, consequently leading to smaller cells [30].
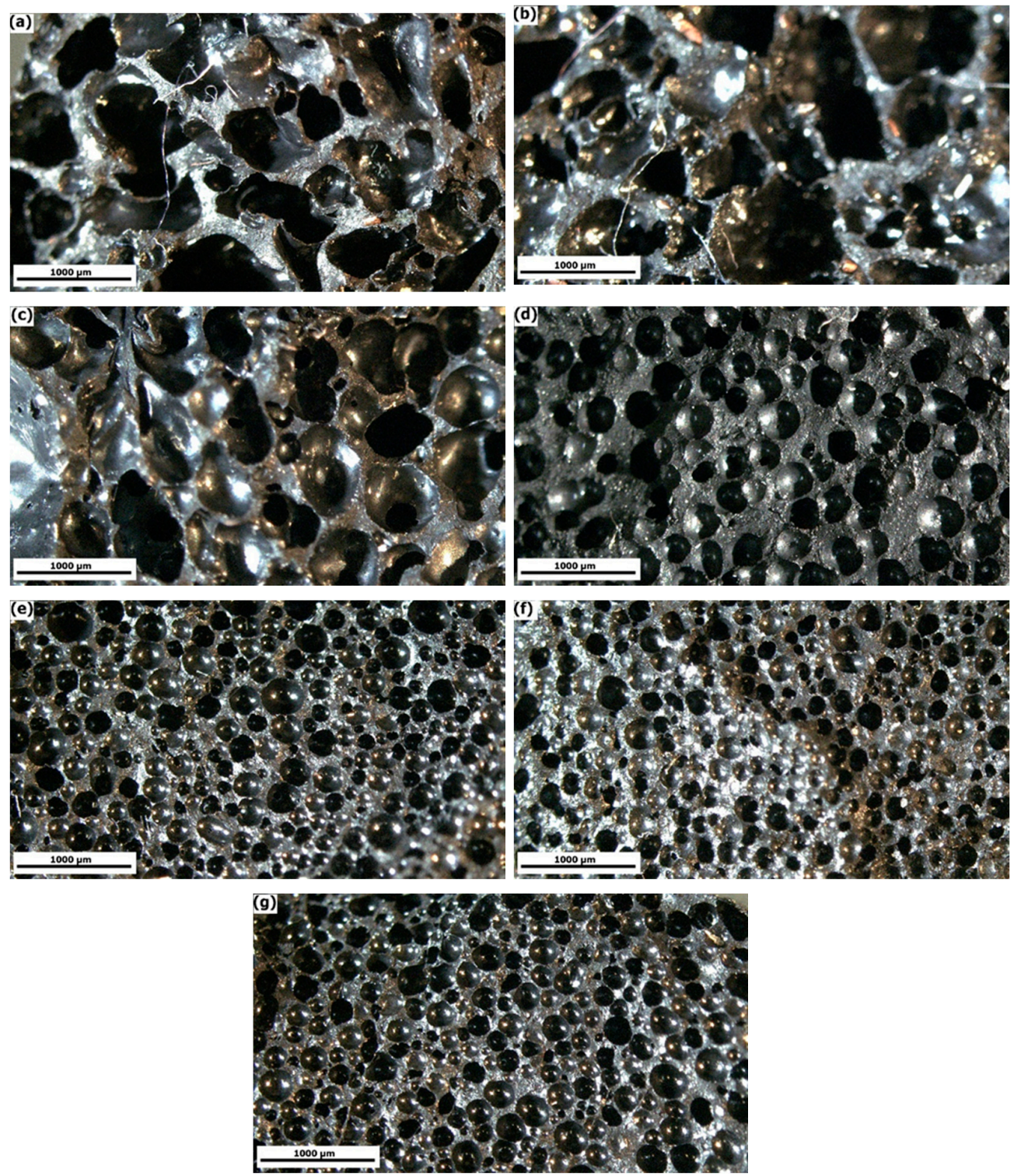

Figure 2. Cell morphology of NR/CNT/GNS nanocomposite foams with different CNT/GNS hybrid content: (a) 0 phr, (b) $0.1 \mathrm{phr}$, (c) $0.25 \mathrm{phr}$, (d) $0.5 \mathrm{phr}$, (e) $1 \mathrm{phr}$, (f) $1.5 \mathrm{phr}$, and (g) $2 \mathrm{phr}$. 
Figure 3 shows the quantitative result of the measured inner cell diameter (or the cell size) of the NR/CNT/GNS foams prepared with various hybrid nanofiller contents as histograms. The cell diameters ranged from 200 to $1000 \mu \mathrm{m}$, depending on CNT/GNS loading. The cell size distribution curve's peak in the S0 sample was at $610 \mu \mathrm{m}$, but it shifted toward lower values with an increase in the CNT/GNS hybrid content (i.e., $110 \mu \mathrm{m}$ for the S2 sample). Moreover, the cell size distribution of the S20 sample had a much narrower distribution compared to the $\mathrm{S} 0$ sample. The distribution of the NR/CNT/GNS foam cells' inner diameters was quantified by calculating the polydispersity index (PDI), based on Equation (2) [31]:

$$
P D I=\frac{D_{w}}{D_{n}}
$$

where $\boldsymbol{D}_{n}=\frac{\sum \boldsymbol{n}_{i} \cdot \boldsymbol{D}_{i}}{\sum \boldsymbol{n}_{i}}$ and $\boldsymbol{D}_{w}=\frac{\sum \boldsymbol{n}_{i} \cdot \boldsymbol{D}_{i}^{2}}{\sum n_{i} \cdot \boldsymbol{D}_{i}}$ are the number and the weighted average of the cell size, respectively.

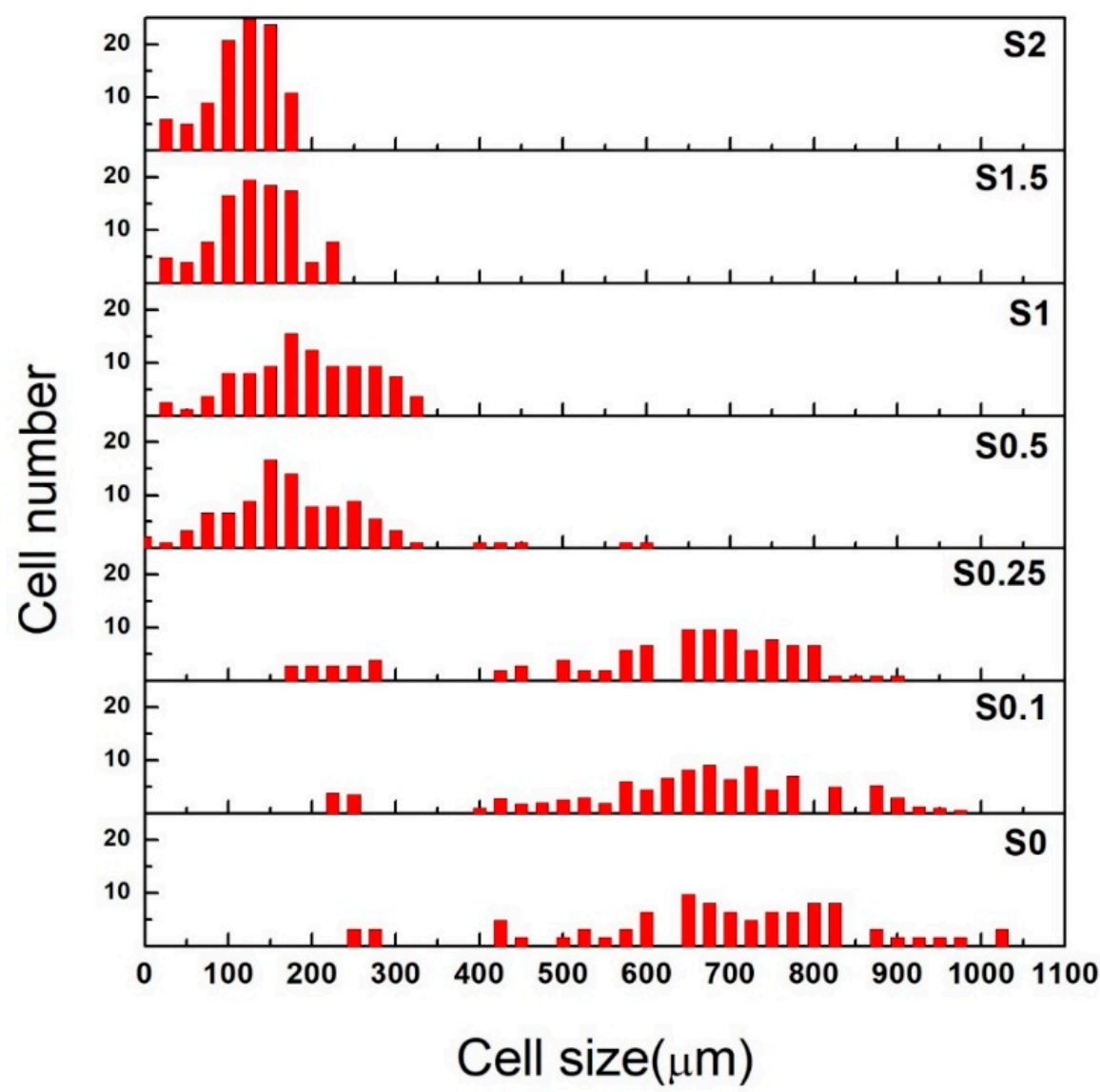

Figure 3. Cell size distribution of NR/CNT/GNS nanocomposite foams.

The PDI value close to unity indicates a very uniform cell size distribution [31], which is essential for developing a product with isotropic mechanical properties. Figure 3 shows that greater uniformity in the cellular structure of the NR/CNT/GNS foams can be obtained by increasing CNT/GNS hybrid content. As previously noted, the NR foam compound's initial modulus and cure rate increased by adding higher amounts of CNT/GNS hybrid nanofiller. In other words, the inhibiting force, which resists the foam cells' expansion, has increased by increasing the hybrid nanofiller loading, while the total amount of expansion is the same. Thus, the average cell size decreased, and the cell size distribution became narrower.

Figure 4 shows the relationship between the hybrid particle content and the average cell size. Additionally, $\mathrm{t}$ a significant reduction in the average cell size in NR foams 
reinforced by hybrid nanoparticles was observed. As mentioned, these results could be related to both the nucleation and the viscosity boosting effect of the nanoparticles. Overall, it was clear that with the addition of the hybrid nanoparticles, the cell size gradually decreased from $800 \mu \mathrm{m}$ to $80 \mu \mathrm{m}$.

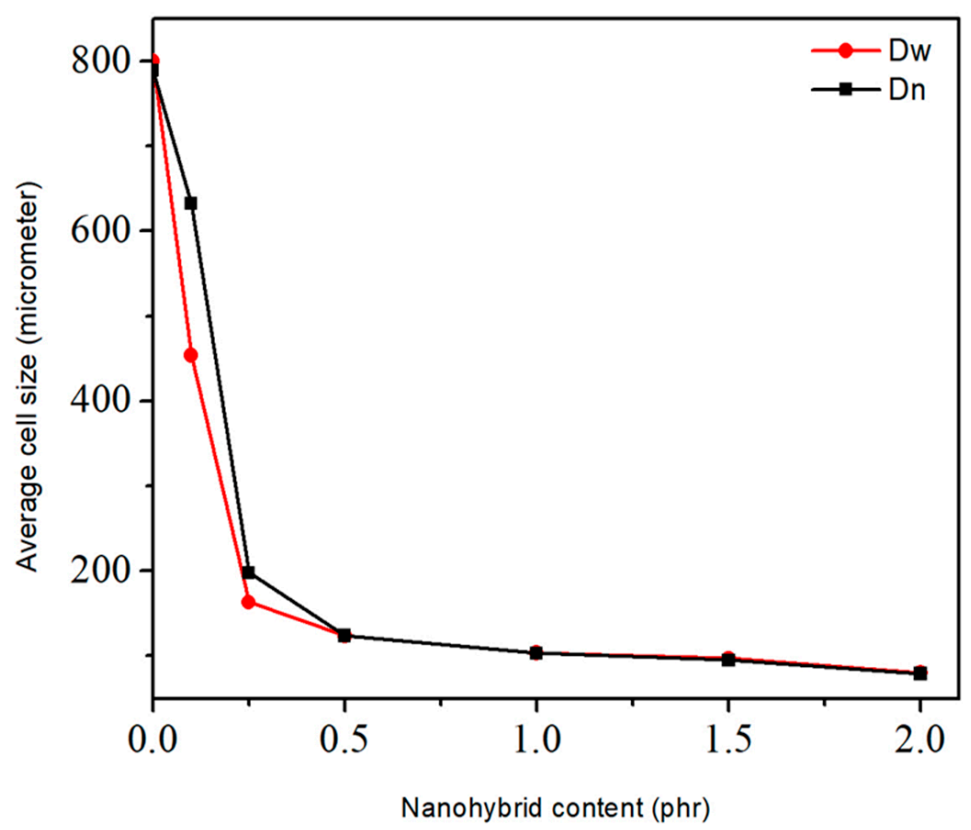

Figure 4. Variation of average cell size of NR/CNT/GNS foam nanocomposites versus. CNT/GNS hybrid content.

\subsection{Hardness and Resilience}

Hardness and resilience tests were used as a criterion to determine the elastic properties of NR/CNT/GNS rubber foams, and the data are illustrated in Figures 5 and 6, respectively. As shown in Figure 5, by adding GNSs and CNTs to the NR matrix, a significant change in hardness was observed with low filler loading levels ( $0.5-1 \mathrm{phr})$. However, the hardness stabilized and did not display statistically significant change beyond 1 phr loading.

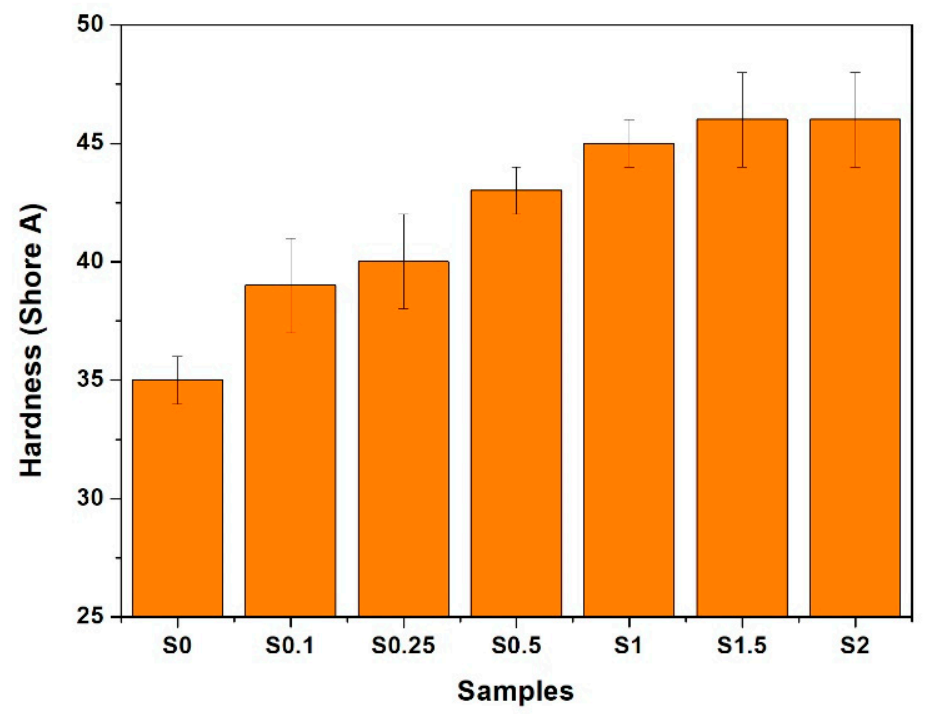

Figure 5. The variation in hardness in NR foams containing different content of GNS/CNT hybrid. 


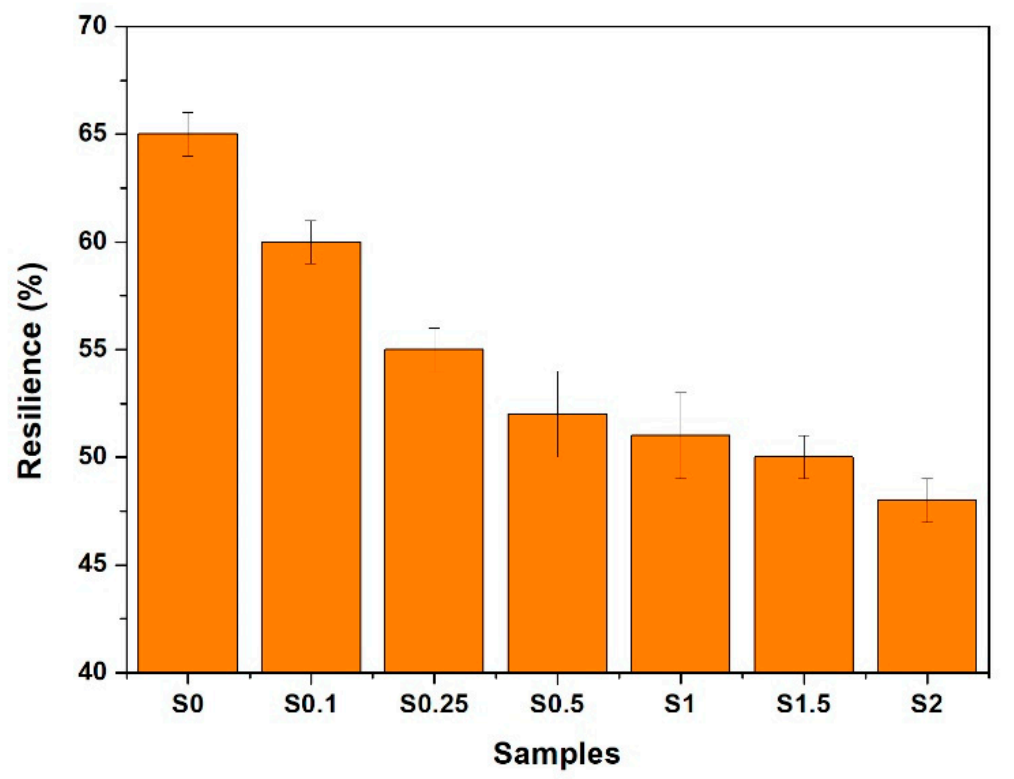

Figure 6. The variation in resilience in NR foams containing different content of GNS/CNT hybrid.

A correlation between the hardness of the foams was observed with the increase in the hybrid filler loading levels, while the correlation between the resilience and the hybrid filler content was inverse. For instance, adding only $0.1 \mathrm{phr}$ of CNT/GNS to the NR foam increased the hardness from 35 to 39 Shore A and decreased the resilience from $65 \%$ to $60 \%$, while adding $2 \mathrm{phr}$ of CNT and GNS had no effect on the hardness while substantially reducing the resilience $(48-50 \%)$. Increasing the CNT/GNS content decreased the resilience because of the strong filler-rubber interaction, higher crosslink density, and lower NR chain flexibility. On the other hand, hardness could increase via either or both mechanisms: hindering the rubber chain mobility caused by higher curing density and filler-rubber interactions and reducing the average foam cell size (discussed above). Similar behavior was observed for polymer solid or foam composites reinforced by other types of nano reinforcements $[18,30]$.

\subsection{Compression Test}

The introduction of nano reinforcement leads to a noticeable change in the mechanical behavior of elastomeric materials under cyclic force. Figure 7 shows the effect of CNT/GNS hybrid content on the stress-strain behavior of the NR/CNT/GNS foams during a cyclic compression test. We found that the modulus and strength (i.e., stress at $50 \%$ strain) of the foams increased steadily with increasing CNT/GNS hybrid content in the NR/CNT/GNS foams. The extremely high mechanical strength of the individual CNTs provides superstrong engineering materials that can sustain stress perfectly. It is well established that nanomaterials have a high reinforcing effect in increasing the modulus of polymer foams [18]. The rubber foams can be considered as a composite of NR/CNT/GNS matrix with a dispersed gas cell phase. Therefore, the foam's compressive stress-strain modulus depends on the mechanical properties of both individual phases and morphology. On the other hand, the moduli of the foams all increased because the interconnected 3-D framework of the CNT/GNS hybrid can effectively resist deformation and withstand force. The formation of the 3-D network of CNT/GNS in a solid polymer matrix has been reported before [24,32]. In addition, the increase in the modulus was expected due to the hardening effect of the CNT/GNS hybrid as a consequence of its stiff nature. As can be noted from Figure 7, increasing the nanofillers' content from 0 to $2 \mathrm{phr}$ improved the compression behavior and increased the stress at 50\% strain from $150 \mathrm{kPa}$ to $440 \mathrm{kPa}$, which are related to higher modulus, smaller cell size, and robust matrices. Thus, an increased CNT/GNS hybrid content can increase the modulus of the foam via the two 
possible mechanisms; the matrices' modulus increased due to the reinforcing effect of the nanofillers caused by a 3-D network of inherently stiff nanomaterial, and reduction of the foam's cell size.
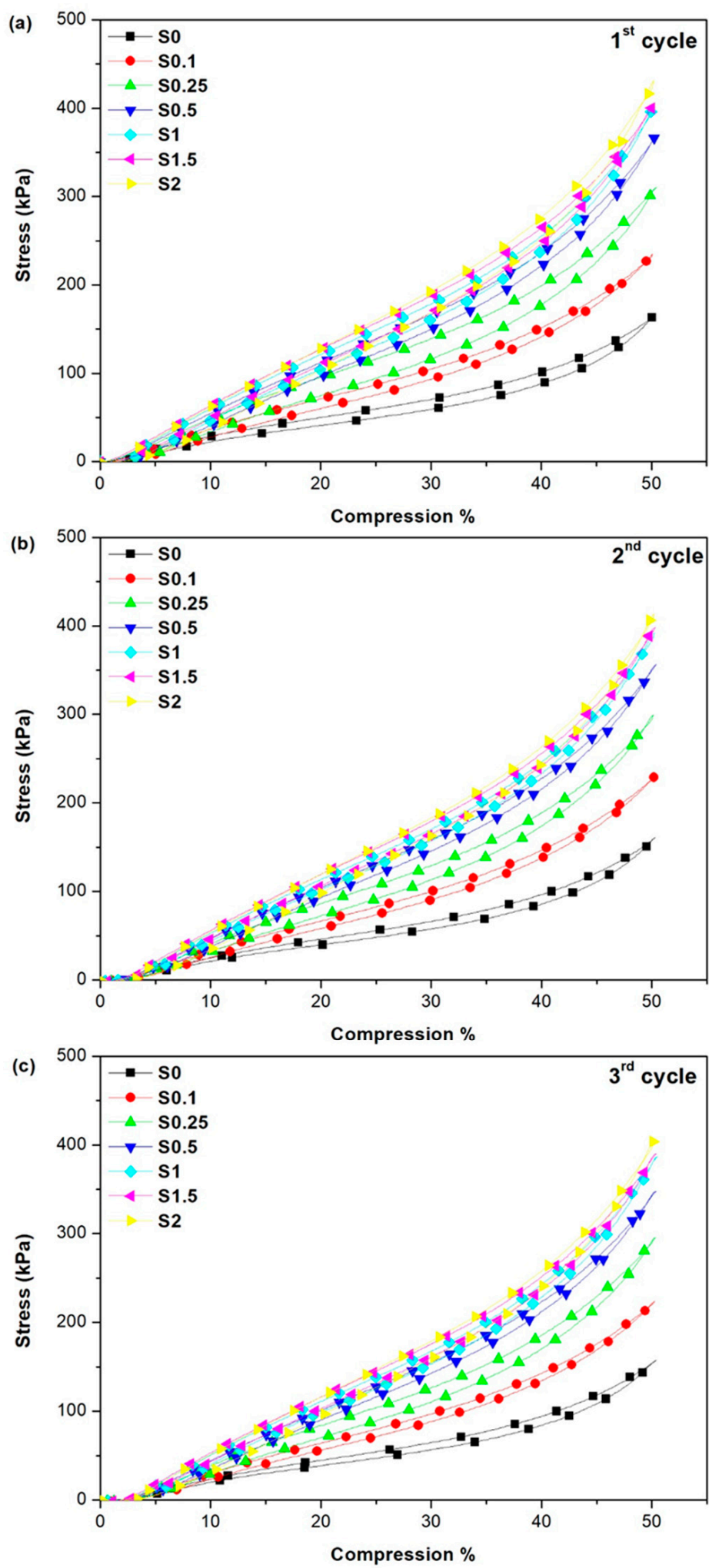

Figure 7. The effect of CNT/GNS hybrid content on the stress-strain behavior of the NR/CNT/GNS foams: (a) first cycle, (b) second cycle, and (c) third cycle. 
Fatigue behavior is associated with a decrease in strength under cyclic loads, localized and progressive damage to the polymer structure due to cyclic loading. This may cause fractures or incomplete cracks after a sufficient number of compressive cycles. The S2 sample displayed the best cyclic stability, which indicates that the CNT/GNS hybrid can change the dynamic molecular properties of NR and enhances its resistance to large deformation due to repeated stress. Moreover, the nanofillers could act as nanobarriers to crack propagation, thereby increasing matrix fatigue resistance.

The evolution of the stress-strain hysteresis loop of each NR/CNT/GNS nanocomposite foam samples with various content of CNT/GNS is provided in the supporting information (Figures S1 to S7) for better comparison. The significant difference in the width of the loops in Figures S1 to S7 proves the important role of the hybrid filler content as a parameter to control rubber deformation and ratcheting progress over stress cycles. Over the first cycle, the rubber blend S0 sample with no filler content presented a wide hysteresis loop indicative of dramatic plastic deformation. The hysteresis loop in samples containing a higher amount of CNT/GNS became narrower than that of the pristine foam. This means that as the magnitude of CNT/GNS content increases, stress-strain hysteresis loops gain higher stiffness and modulus of elasticity. By progressing loading cycles, the area within the individual hysteresis loops gradually drops, indicating decay in ratcheting rate in composite samples. The width of the loop or the area between the loading and unloading cycle corresponds to dissipated energy in tested samples over the loading/unloading cycles leading to heat build-up in specimens [33]. Thus, the narrower hysteresis of the foam samples with higher content of CNT/GNS hybrid nanofiller revealed their lower ability to dissipate the exerted energy which is in agreement with mechanical results observed above.

\subsection{Thermal Degradation}

The thermo-oxidative stability results of NR/CNT/GNS foams obtained from the TGA and its derivative differential thermogravimetry (DTG) are shown in Figure 8. It can be seen that all the samples have a two-step thermal degradation in TGA curves (Figure 8a). Additionally, the DTG plots in Figure 8b showed two distinct peaks that correspond to the local maximum rates of weight loss in all nanofillers' contents. The first step around $400{ }^{\circ} \mathrm{C}$ was related to the decomposition of small molecules and additives such as oil, blowing agent, etc. [34]. The second degradation step occurred in the region of $450-500{ }^{\circ} \mathrm{C}$ and was related to the NR degradation. In Table 2, the thermal properties of the prepared foams are directly compared to highlight the effect of CNT/GNS hybrid nanofiller on the degradation of the NR foams. It was observed that the degradation temperatures of nanocomposites at $5 \%$ and $50 \%$ weight loss are higher than that of raw rubber and with increasing hybrid nanofiller content. The percentage of remained ash rose from $5.7 \%$ to $12.23 \%$ by weight. A significant temperature rise was also observed at $50 \%$ and $5 \%$ weight loss, which increased from $407{ }^{\circ} \mathrm{C}$ to $414{ }^{\circ} \mathrm{C}$ and from $339{ }^{\circ} \mathrm{C}$ to $346{ }^{\circ} \mathrm{C}$, respectively. This increase could be related to the interaction between NR and the nanomaterials, limiting the release of gases from the heat degradation as it causes them to cross a more tortuous path. The increase in the thermal stability of polymer composites having well-dispersed nanofiller has been reported in the literature [35].

The maximum DTG peaks in the samples were elevated by increasing the nanofillers' content in both weight loss steps. The addition of inorganic fillers such as the GNS/CNT hybrid causes higher thermal resistance in the rubber due to their higher inherent thermal resistance compared to the NR. Therefore, the thermal stability of the nanocomposites increases when the CNT and GNS are incorporated, and these nanomaterials can act as a delaying agent in the degradation of rubber matrices. This can be ascribed to the ability of the carbon-based fillers that contribute to thermally protect the polymer matrix and hinder the transport of degradation volatiles through the matrix by the formation of a tortuous path [36]. The weight of the sample at the first $\mathrm{T}_{\text {Peak }}$ decreased slightly from $50.54 \%$ to 
$50.18 \%$; however, a significant rise in the weight of the samples was observed at the second $\mathrm{T}_{\text {peak }}$, which increased dramatically from $6.77 \%$ to $14.28 \%$.
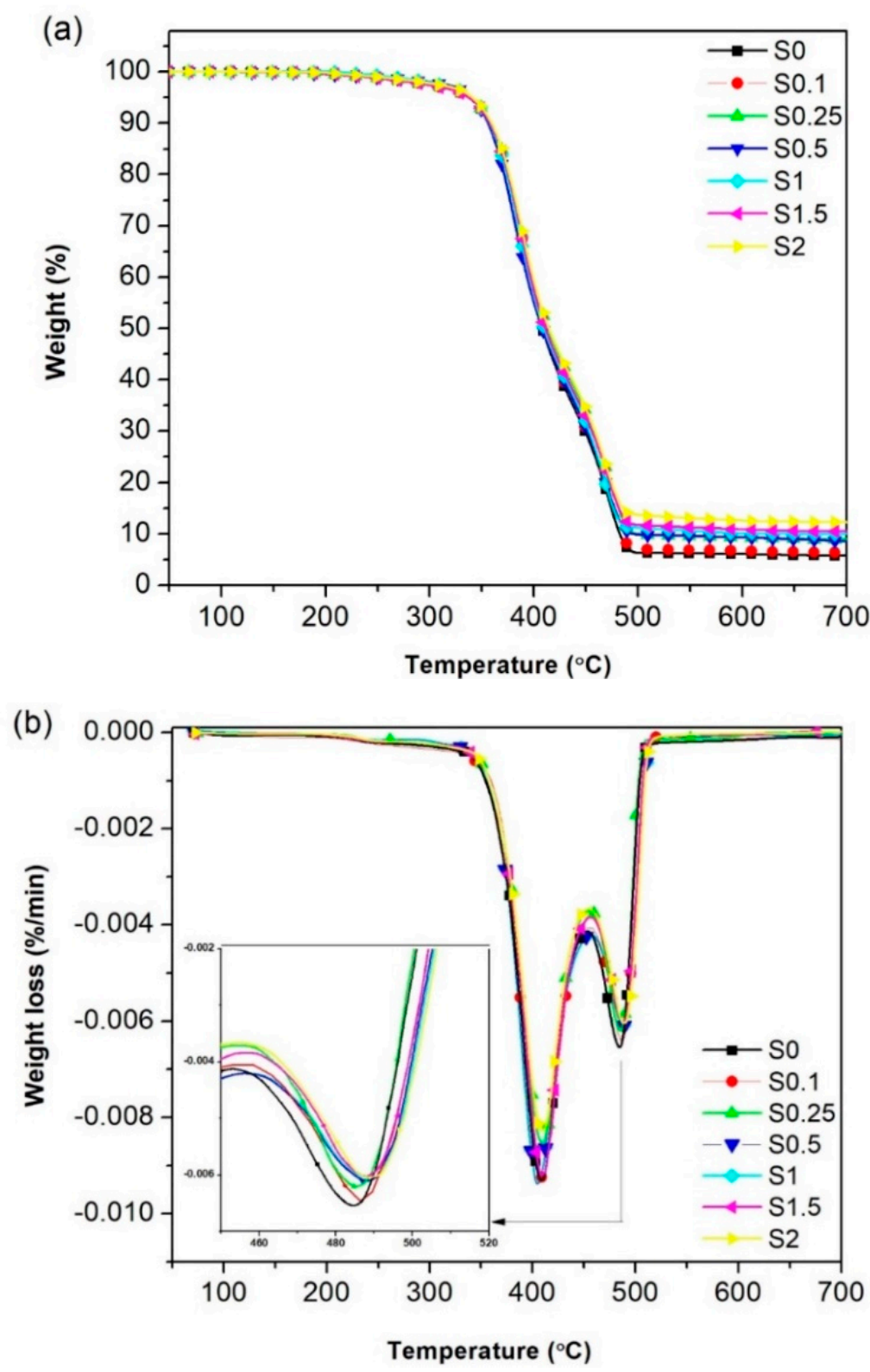

Figure 8. Thermal degradation behavior of the NR/CNT/GNS foams with different hybrid nanofiller content: (a) TGA curve and (b) DTG curve.

\subsection{Dynamical Mechanical Analysis (DMTA)}

DMTA is a technique used to analyze and characterize foam nanocomposite samples based on their response to an applied dynamical, mechanical, and thermal force. DMTA results are often expressed in terms of the storage modulus ( $\left.E^{\prime}\right)$, loss modulus $\left(E^{\prime \prime}\right)$, and loss factor $(\tan \delta)$, which describe the ability of the materials to lose energy as heat to mean damping and their ability to revert to their original shape and size from the deformation when the oscillating applied force is removed.

The $\mathrm{E}^{\prime}$ test data used to describe the stiffness of composite materials and their variation as a function of temperature is presented in Figure 9a for all foam nanocomposite samples. The observed increase in $E^{\prime}$ values above $T_{g}$ with increased GNS/CNT content can be attributed to increasing GNS/CNT hybrid nanofiller concentration. It should be noted that this increase in $E^{\prime}$ is negligible at temperatures below the glass transition $\left(T_{g}\right)$ due to 
the rigidity of the nanomaterials. As the temperature rose from $-100{ }^{\circ} \mathrm{C}$ to $-50{ }^{\circ} \mathrm{C}$, the $\mathrm{E}^{\prime}$ values decreased for all samples. A substantial decrease in $\mathrm{E}^{\prime}$ was seen in the temperature range between $-60{ }^{\circ} \mathrm{C}$ and $-40{ }^{\circ} \mathrm{C}$ of the curve related to the matrix's glass transition temperature. The observed increase in $\mathrm{E}^{\prime}$ values above $\mathrm{T}_{\mathrm{g}}$ can be attributed to the interaction between the polymer matrix (NR) and the CNT/GNS hybrid nanofillers that led to the reinforcement phenomenon. Strong interactions preserve the porous structure against temperature rise [37]. E" is a material's response by losing energy to the surroundings due to the applied external oscillating force. Figure $9 b$ indicates the variation of $E^{\prime \prime}$ for NR/CNT/GNS nanocomposite foams as a function of temperatures. It was noted that the E" curve of NR/CNT/GNS containing a higher amount of CNT/GNS hybrid nanofiller showed a slightly wider peak in the E" curve, which suggests a broad relaxation time distribution of NR chains. It is well-known that the broadness of the peak in multicomponent polymeric systems is primarily controlled by heterogeneity: either the intrinsic differences among components' relaxation properties (dynamic heterogeneity) or their detailed state of local concentration fluctuations (local heterogeneity) [38]. The dispersion of rigid nanoparticles in polymeric matrices resulting in local and dynamic heterogeneity can lead to significant damping capability, which is mutually correlated with a broader peak of E".
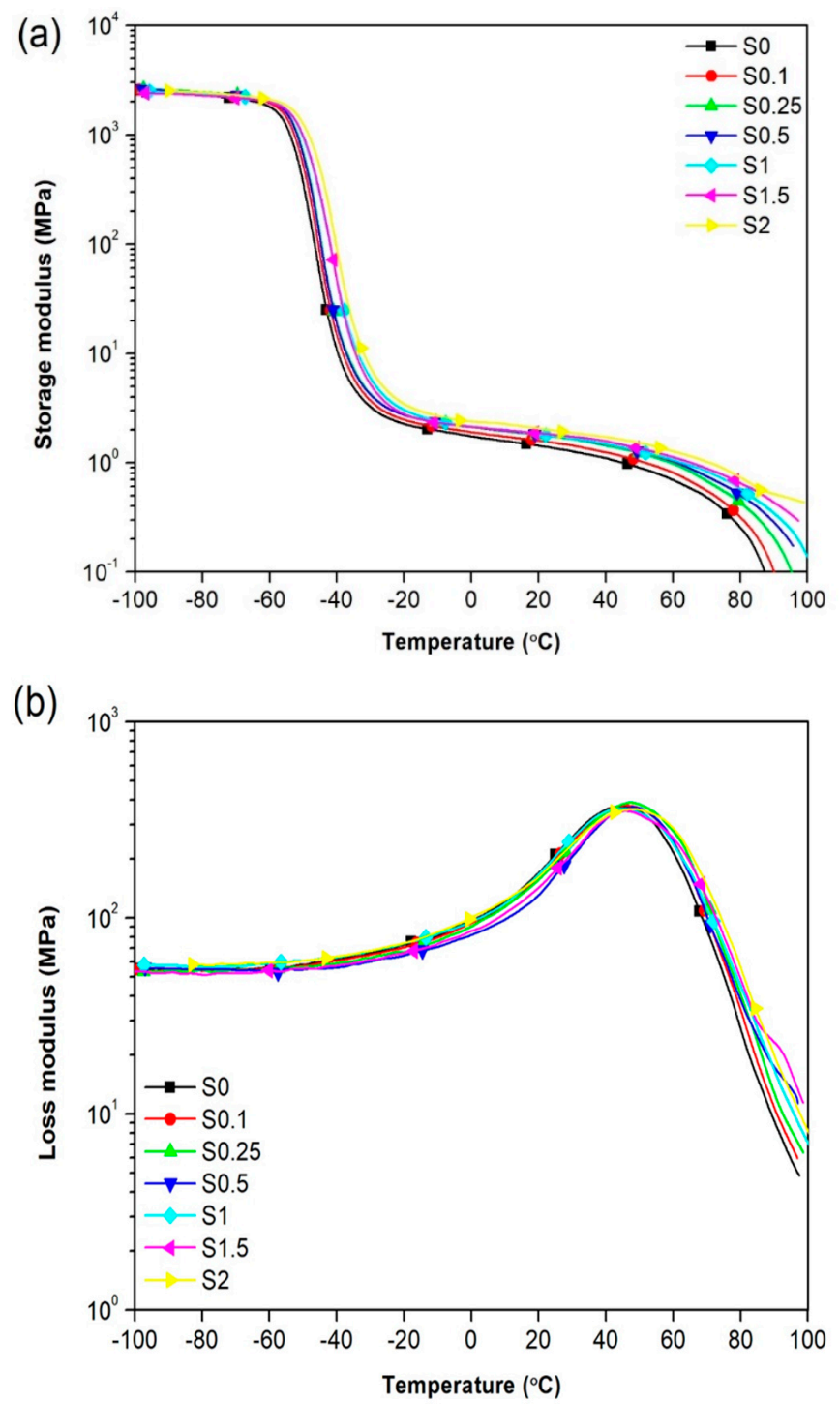

Figure 9. Cont. 


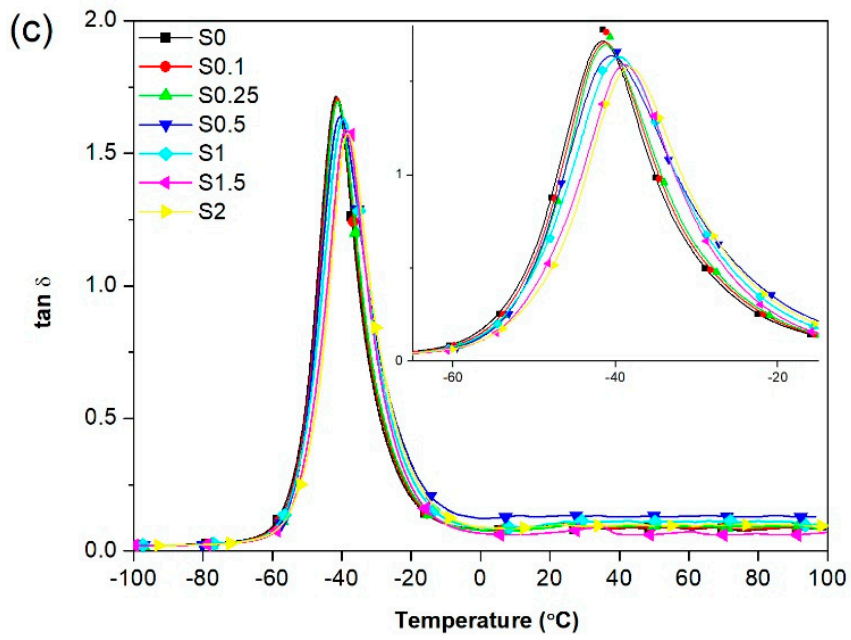

Figure 9. Dynamic properties of NR/CNT/GNS nanocomposite foams as a function of temperature: (a) variation of storage modulus ( $\left.E^{\prime}\right)$, (b) variation of loss modulus ( $\left.E^{\prime \prime}\right)$, and (c) variation of dissipation peak $(\tan \delta)$.

Tan $\delta$, also called the loss factor, is calculated from the ratio of loss modulus to storage modulus $\left(E^{\prime \prime} / E^{\prime}\right)$. The tan $\delta$ curves are plotted as a function of temperature for all samples, as shown in Figure 9c, and the data are further tabulated in Table 3. Comparing the maximum $\mathrm{T}_{\mathrm{g}}$ values of the samples provided in Table 4 , the $\mathrm{T}_{\mathrm{g}}$ increased from $42.14{ }^{\circ} \mathrm{C}$ to $52.29{ }^{\circ} \mathrm{C}$. It is observed in Figure 9 and that Table 3 peak of this curve $\left(\tan \delta_{\max }\right)$ decreased with increasing CNT and GNS amount. The results show that the glass transition temperature of the S0 samples increased slowly from $-45.77{ }^{\circ} \mathrm{C}$ for the S2 sample to $-38.69{ }^{\circ} \mathrm{C}$. This could be due to the physical interactions between the nanofillers and the rubber matrix. Figure $9 \mathrm{c}$ shows that the $\mathrm{T}_{\mathrm{g}}$ of the nanocomposite had a slight transition to higher temperatures. This increase in $\mathrm{T}_{\mathrm{g}}$ could be correlated to a restriction of the mobility of the segments in the matrix in the presence of carbon-based nanofillers $[39,40]$.

Table 3. Thermal degradation characteristics of the NR/CNT/GNS Foam.

\begin{tabular}{|c|c|c|c|c|c|c|c|}
\hline \multirow{2}{*}{ Samples } & \multicolumn{2}{|c|}{ 1st Step of Weight Loss } & \multicolumn{2}{|c|}{ 2nd Step of Weight Loss } & \multirow{2}{*}{$\mathrm{T}_{5}\left({ }^{\circ} \mathrm{C}\right)$} & \multirow{2}{*}{$\mathrm{T}_{50}\left({ }^{\circ} \mathrm{C}\right)$} & \multirow{2}{*}{ Ash (\%) } \\
\hline & $\mathrm{T}_{\text {peak1 } 1}\left({ }^{\circ} \mathrm{C}\right)$ & $W_{1}(\%)$ & $\mathrm{T}_{\text {peak2 }}\left({ }^{\circ} \mathrm{C}\right)$ & $W_{2}(\%)$ & & & \\
\hline So & 405.14 & 50.54 & 485.11 & 6.77 & 339 & 407 & 5.7 \\
\hline S0.1 & 405.88 & 50.43 & 486.07 & 8.31 & 339 & 407 & 6.3 \\
\hline S0.25 & 408.55 & 50.78 & 485.98 & 9.92 & 340 & 408 & 8.50 \\
\hline S0.5 & 409.15 & 50.23 & 487.59 & 10.76 & 340 & 409 & 8.49 \\
\hline S1 & 410.15 & 50.68 & 487.58 & 11.93 & 341 & 411 & 10.03 \\
\hline S1.5 & 410.25 & 49.89 & 489.01 & 12.65 & 344 & 413 & 10.43 \\
\hline $\mathrm{S} 2$ & 410.87 & 50.18 & 489.32 & 14.28 & 346 & 414 & 12.23 \\
\hline
\end{tabular}

$\mathrm{T}_{\text {Peak }}$ : Maximum temperature of the DTG peak; W: Weight of the sample at $\mathrm{T}_{\text {Peak }} ; \mathrm{T}_{5}$ : Temperature at $5 \%$ of weight loss; $\mathrm{T}_{50}$ : Temperature at $50 \%$ of weight loss.

Table 4. Variation in $\mathrm{T}_{\mathrm{g}}$ (Measured from the Peak of the $\tan \delta$ Curve).

\begin{tabular}{ccc}
\hline $\mathbf{T}_{\mathbf{g}}\left({ }^{\circ} \mathbf{C}\right)$ & Intensity of $\tan \delta$ Peak at $\mathbf{T}_{\mathbf{g}}$ & Sample Code \\
\hline 42.14 & 1.92 & $\mathrm{~S} 0$ \\
45.66 & 1.90 & $\mathrm{~S} 0.1$ \\
47.09 & 1.89 & $\mathrm{~S} 0.25$ \\
47.78 & 1.82 & $\mathrm{~S} 0.5$ \\
48.68 & 1.81 & $\mathrm{~S} 1$ \\
50.48 & 1.77 & $\mathrm{~S} 1.5$ \\
52.29 & 1.75 & $\mathrm{~S} 2$ \\
\hline
\end{tabular}




\section{Conclusions}

In this study, the effect of incorporating GNS/CNT on the curing behavior, the foam morphology, and the mechanical and thermal properties of the NR foams was investigated. The curing characteristics showed that the addition of a hybrid nanofiller in the NR reduced the cure start time $\left(\mathrm{T}_{\mathrm{s}}\right)$ and sped up the overall curing reaction by limiting the polymer chains' mobility. It was also observed that the GNS/CNT incorporation resulted in greater hardness and lower resilience of the NR composites, which was attributed to the good interaction between the polymer matrix and the physical hybrid of CNT/GNS. The compression test results showed that the addition of the nanomaterials increased the compressive strength of all formulations. The CNT/GNS hybrid nanofillers provided the natural rubber with better resistance to large deformation when exposed to repeated stress cycles (fatigue). The DMTA results revealed that the addition of CNT/GNS nanohybrid into the natural rubber matrix provided higher storage modulus in the foam samples due to the nanohybrid material's inherent high hardness and modulus. It was also shown that the peak of the loss factor in nanocomposites decreased with increasing nanofiller content and slightly increased the glass transition temperature $\left(T_{g}\right)$. The TGA study indicated that the addition of GNS/CNT hybrid caused higher thermal stability in the NR foams by acting as a delaying agent in the degradation of the rubber matrix. With the increase in CNT/GNS content, the residual weight increased by up to $10 \%$. The morphological results from optical microscopy also illustrated that increasing the CNT/GNS hybrid nanofiller content produced more cells with smaller cell sizes and cell wall thickness. Samples with lower nanofiller content have elongated and irregular cells. Contrarily, formulations with higher GNS/CNT hybrid loading levels resulted in cells that were more spherical and closer in size to each other with an overall improved uniformity and narrower distribution.

Supplementary Materials: The following are available online at https://www.mdpi.com/article/10 .3390/polym13142346/s1. Figure S1. Evolution of stress-strain hysteresis loops for NR nanocomposite foam samples with $0 \mathrm{phr}$ of physical hybrid of CNT/GNS at different cycles. Figure S2. Evolution of stress-strain hysteresis loops for NR nanocomposite foam samples with $0.1 \mathrm{phr}$ of physical hybrid of CNT/GNS at different cycles. Figure S3. Evolution of stress-strain hysteresis loops for NR nanocomposite foam samples with $0.25 \mathrm{phr}$ of physical hybrid of CNT/GNS at different cycles. Figure S4. Evolution of stress-strain hysteresis loops for NR nanocomposite foam samples with 0.5 phr of physical hybrid of CNT/GNS at different cycles. Figure S5. Evolution of stress-strain hysteresis loops for NR nanocomposite foam samples with 1 phr of physical hybrid of CNT/GNS at different cycles. Figure S6. Evolution of stress-strain hysteresis loops for NR nanocomposite foam samples with 1.5 phr of physical hybrid of CNT/GNS at different cycles. Figure S7. Evolution of stress-strain hysteresis loops for NR nanocomposite foam samples with 2 phr of physical hybrid of CNT/GNS at different cycles.

Author Contributions: Conceptualization, E.E. and A.V.; methodology, E.E. and A.V.; software, S.S., E.E. and A.V.; validation, E.E., A.V. and T.H.M.; formal analysis, S.S.; investigation, S.S. and E.E.; resources, E.E. and A.V.; data curation, S.S.; writing—original draft preparation, S.S.; writing-review and editing, E.E., A.V., G.N. and T.H.M.; visualization, E.E., A.V. and T.H.M.; supervision, E.E., A.V. and E.S., G.N.; project administration, E.E., S.S. and A.V.; funding acquisition, E.E., G.N. and E.S. All authors have read and agreed to the published version of the manuscript.

Funding: This research received no external funding.

Institutional Review Board Statement: Not applicable.

Informed Consent Statement: Not applicable.

Data Availability Statement: Not applicable.

Conflicts of Interest: The authors declare no conflict of interest. 


\section{References}

1. Rodríguez-Pérez, M.; Duijsens, A.; de Saja, J. Effect of addition of EVA on the technical properties of extruded foam profiles of low-density polyethylene/EVA blends. J. Appl. Polym. Sci. 1998, 68, 1237-1244. [CrossRef]

2. Tejeda, E.H.; Sahagun, C.Z.; Nunez, R.G.; Rodrigue, D. Morphology and mechanical properties of foamed polyethylenepolypropylene blends. J. Cell. Plast. 2005, 41, 417-435. [CrossRef]

3. Esmizadeh, E.; Arjmandpour, M.; Vahidifar, A.; Naderi, G.; Dubois, C. Preparation and characterization of silicone rubber/graphene nanosheets nanocomposites by in-situ loading- of the coupling agent. J. Compos. Mater 2019, 53, 3459-3468. [CrossRef]

4. Oliveira, A.; Larocca, N.M.; Pessan, L.A. Effects of mixing protocol on the performance of nanocomposites based on polyamide 6/acrylonitrile-butadiene-styrene blends. Polym. Eng. Sci. 2012, 52, 1909-1919. [CrossRef]

5. Maron, G.; Noremberg, B.S.; Alano, J.H.; Pereira, F.R.; Deon, V.G.; Santos, R.C.R.; Freire, V.N.; Velentini, A.; Carreno, N.L.V. Carbon fiber/epoxy composites: Effect of zinc sulphide coated carbon nanotube on thermal and mechanical properties. Polym. Bull. 2018, 75, 1619-1633. [CrossRef]

6. Nogueira de Melo, C.C.; Beatrice, C.A.G.; Pessari, L.A.; De Oliveira, A.D.; Machado, F.M. Analysis of nonisothermal crystallization kinetics of graphene oxide-reinforced polyamide 6 nanocomposites. Thermochim. Acta 2018, 667, 111-121. [CrossRef]

7. Gómez, H.; Ram, M.K.; Alvi, F.; Villalba, P.; Stefanakos, E.; Kumar, A. Graphene-conducting polymer nanocomposite as novel electrode for supercapacitors. J. Power Sources 2011, 196, 4102-4108. [CrossRef]

8. Sonia, A.; Dasan, K.P. Celluloses microfibers (CMF)/poly (ethylene-co-vinyl acetate) (EVA) composites for food packaging applications: A study based on barrier and biodegradation behavior. J. Food Eng. 2013, 118, 78-89. [CrossRef]

9. Marini, J.; Pollet, E.; Averous, L.; Bretas, R.E.S. Elaboration and properties of novel biobased nanocomposites with halloysite nanotubes and thermoplastic polyurethane from dimerized fatty acids. Polymer 2014, 55, 5226-5234. [CrossRef]

10. Yakobson, B.I.; Smalley, R.E. Fullerene nanotubes: C 1,000,000 and beyond: Some unusual new molecules-long, hollow fibers with tantalizing electronic and mechanical properties—have joined diamonds and graphite in the carbon family. Am. Sci. 1997, 85, 324-337.

11. Rafiee, M.A.; Rafiee, J.; Srivastava, I.; Wang, Z.; Song, H.; Yu, Z.; Koratkar, N. Fracture and fatigue in graphene nanocomposites. Small 2010, 6, 179-183. [CrossRef] [PubMed]

12. Nia, A.S.; Binder, W.H. Graphene as initiator/catalyst in polymerization chemistry. J. Prog. Polym. Sci. 2017, 67, 48-76.

13. Vahidifar, A.; Nouri-Khorasani, S.; Park, C.B.; Naguib, H.E.; Khonakdar, H.A. Fabrication and characterization of closed-cell rubber foams based on natural rubber/carbon black by one-step foam processing. Ind. Eng. Chem. Res. 2016, 55, 2407-2416. [CrossRef]

14. Mosanenzadeh, S.G.; Naguib, H.E.; Park, C.B.; Atalla, N. Development, characterization, and modeling of environmentally friendly open-cell acoustic foams. Polym. Eng. Sci. 2013, 53, 1979-1989. [CrossRef]

15. Park, C.B.; Padareva, V.; Lee, P.C.; Naguib, H.E. Extruded open-celled LDPE-based foams using non-homogeneous melt structure. J. Polym. Eng. 2005, 25, 239-260. [CrossRef]

16. Lee, P.C.; Wang, J.; Park, C.B. Extruded open-cell foams using two semicrystalline polymers with different crystallization temperatures. Ind. Eng. Chem. Res. 2006, 45, 175-181. [CrossRef]

17. Vahidifar, A.; Esmizadeh, E.; Rodrigue, D. Effect of the simultaneous curing and foaming kinetics on the morphology development of polyisoprene closed cell foams. J. Elastomery 2018, 2, 3-18.

18. Vahidifar, A.; Esmizadeh, E.; Nouri Khorasani, S.; Rodrigue, D. Morphological, rheological, and mechanical properties of hybrid elastomeric foams based on natural rubber, nanoclay, and nanocarbon black. Polym. Compos. 2019, 40, 4289-4299. [CrossRef]

19. Esmizadeh, E.; Naderi, G.; Yousefi, A.A.; Milone, C. Thermal and Morphological Study of Epoxy Matrix with Chemical and Physical Hybrid of Nanoclay/Carbon Nanotube. J. Miner. Met. Mater. Soc. 2016, 68, 362-373. [CrossRef]

20. Amerio, E.; Sangermano, M.; Malucelli, G.; Priola, A.; Voit, B. Preparation and characterization of hybrid nanocomposite coatings by photopolymerization and sol-gel process. J. Polym. 2005, 46, 11241-11246. [CrossRef]

21. Song, J.; Li, X.; Tian, K.; Ma, L.; Li, W.; Yao, S. Thermal conductivity of natural rubber nanocomposites with hybrid fillers. J. Chem. Eng. 2019, 27, 928-934. [CrossRef]

22. Ponnamma, D.; Sadasivuni, K.K.; Strankowski, M.; Guo, Q.; Thomas, S. Synergistic effect of multi walled carbon nanotubes and reduced graphene oxides in natural rubber for sensing application. J. Soft Matter 2013, 43, 10209-10428. [CrossRef]

23. King, P.J.; Khan, U.; Lotya, M.; De, S.; Coleman, J.N. Improvement of Transparent Conducting Nanotube Films by Addition of Small Quantities of Graphene. J. ACS Nano 2010, 4, 3535-4332. [CrossRef] [PubMed]

24. Shim, W.; Kwon, Y.; Jeon, S.; Yu, W. Optimally conductive networks in randomly dispersed CNT:graphene hybrids. J. Sci. Rep. 2015, 5, 16568. [CrossRef]

25. Esmizadeh, E.; Naderi, G.; Barmar, M. Effect of organo-clay on properties and mechanical behavior of Fluorosilicone rubber. Fibers Polym. 2014, 15, 2376-2385. [CrossRef]

26. Shokrzadeh, A.; Naderi, G.; Esmizadeh, E. Mechanical and rheological properties of calcium carbonate-filled ethylene propylene diene elastomer reinforced by metallic acrylate salt. Fibers Polym. 2014, 15, 1694-1700. [CrossRef]

27. Arroyo, M.; Lopez-manchado, M.A.; Herrero, B. Organo-montmorillonite as substitute of carbon black in natural rubber compounds. Polymer 2003, 44, 2447-2453. [CrossRef] 
28. Kim, J.-H.; Koh, J.S.; Choi, K.C.; Yoon, J.M.; Kim, S.Y. Effects of foaming temperature and carbon black content on the cure characteristics and mechanical properties of natural rubber foams. J. Ind. Eng. Chem. 2007, 13, 198-205.

29. Choi, S.S.; Park, B.H.; Song, H. Influence of filler type and content on properties of styrene-butadiene rubber (SBR) compound reinforced with carbon black or silica. Polym. Adv. Technol. 2014, 15, 122-127. [CrossRef]

30. Vahidifar, A.; Nouri Khorasani, S.; Park, C.B.; Khonakdar, H.A.; Reuter, U.; Naguib, H.; Esmizadeh, E. Towards the development of uniform closed cell nanocomposite foams using natural rubber containing pristine and organo-modified nanoclays. RSC Adv. 2016, 6, 53981-53990. [CrossRef]

31. Goel, S.K.; Beckman, E.J. Generation of microcellular polymeric foams using supercritical carbon dioxide. II: Cell growth and skin formation. Polym. Eng. Sci. 1994, 34, 1148-1156. [CrossRef]

32. al Hartomy, O.A.; Al-Ghamdi, A.; Al-Salamy, F.; Dishovsky, N.; Shtarkova, R.; Iliev, V.; El-Tantawy, F. Effect of carbon nanotubes and graphene nanoplatelets on the dielectric and microwave properties of natural rubber composites. J. Adv. Compos. Mater. 2013, 22, 361-376. [CrossRef]

33. Vahidifar, A.; Esmizadeh, E.; Naderi, G.; Varvani-Farahani, A. Ratcheting response of nylon fiber reinforced natural rubber/styrene butadiene rubber composites under uniaxial stress cycle. Fatigue Fract. Eng. Mater. Struct. 2017, 41, 348-357. [CrossRef]

34. Zakaria, Z.; Ariff, Z.M.; Sipaut, C.S. Effect of Foaming Temperature on Morphology and Compressive Properties of Ethylene propylene diena monomer rubber (EPDM) Foam. Malays. Polym. J. 2007, 2, 22-30.

35. Hemmati, M.; Narimani, A. Study on the electrical and rheological percolation threshold of single-walled carbon nanotubereinforced thermoplastic elastomer based on polypropylene/ethylene-propylene-diene monomer nanocomposite. J. Thermoplast. Compos. Mater. 2015, 28, 930-949.

36. Leszczyńska, A.; Njuguna, J.; Pielichowski, K.; Banerjee, J.R. Polymer/montmorillonite nanocomposites with improved thermal properties: Part I. Factors influencing thermal stability and mechanisms of thermal stability improvement. Thermochim. Acta 2007, 453, 75-96. [CrossRef]

37. Song, P.; Cao, Z.; Cai, Y.; Zhao, L.; Fang, Z.; Fu, S. Fabrication of exfoliated graphene-based polypropylene nanocomposites with enhanced mechanical and thermal properties. Polymer 2011, 52, 4001-4010. [CrossRef]

38. Faghihi, F.; Mohammadi, N.; Hazendonk, P. Effect of Restricted Phase Segregation and Resultant Nanostructural Heterogeneity on Glass Transition of Nonuniform Acrylic Random Copolymers. J. Macromol. 2011, 44, 1729-2394. [CrossRef]

39. Ismail, H.; Pasbakhsh, P.; Fauzi, M.N.; AbuBakar, A. Morphological, thermal and tensile properties of halloysite nanotubes filled ethylene propylene diene monomer (EPDM) nanocomposites. Polym. Test. 2008, 27, 841-850. [CrossRef]

40. Alipour, A.; Naderi, G.; Bakhshandeh, G.R.; Vali, H.; Shokoohi, S. Elastomer nanocomposites based on NR/EPDM/organoclay: Morphology and properties. Int. Polym. Process. 2011, 26, 48-55. [CrossRef] 